\title{
Feminist Re-writing in Angela Carter's The Bloody Chamber
}

\section{P.Priyanka}

M.Phil. English, Seethalakshmi Ramaswami College, Tiruchirappalli, Tamil Nadu, India Email:udayapriya195@gmail.com

\begin{abstract}
The Bloody Chamber is the first well received work of Angela Carter. Angela Carter, the feminist writer of twentieth century presents stories free from patriarchal influence. She has re-written the popular folk and fairy tales like Red Riding Hood, Blue Beard, Sleeping Beauty in feminist perspective. In the course of rewriting the tales, she alters the original plot to give an unexpected end. The Bloody Chamber and other short stories published in 1979 presents the modern feminist want for a strong woman in literature. She has employed magical realism in her stories to give a realistic view of the modern world along with magical elements. She has undermined the gender roles of masculinity and femininity. Blue Beard is a folk tale written by Charles Perrault in which a man named Blue Beard murders his wives. This plot is taken by Angela Carter and she has created strong, independent and witty women characters. This paper discuss the effect of patriarchal narration and fruitful result when the phallocentrism is removed from the plot.
\end{abstract}

Keywords - "The Bloody Chamber", Angela Carter.

The Bloody Chamber and Other Stories uses the traditional western European fairy tale narrative in gothic mode. Angela Carter has not just re-written the tales with a subversive feminist twist. Charles Perrault's fairy tale Blue Beard and Angela Carter's The Bloody Chamber are strikingly different from each other in length and tone. Her work has produced shock waves for a significant number of readers, who are outraged on their recognition that the bedtime stories of their childhood has newly configured as tales of sex and violence. She said, 'My intention was not to do "versions" or, as the American edition of the book said, horribly, "adult" fairy tales, but to extract the latent content from the traditional stories and to use it as the beginnings of new stories'. (Angela Carter, The Bloody Chamber. $x$ ) Carter says the latent content is violently sexual. With magical realism technique Angela Carter has given the touch of fairy tale to the twentieth-century story. In a letter to her friend Robert Coover, she wrote, 'I really do believe that a fiction absolutely self-conscious of itself as a different form of human experience than reality (that is, not a logbook of events) can help to transform reality itself.' (xii) Hence, Angela Carter wrote the stories hoping for a better social change.

The History of Blue Beard or Female Curiosity is a fairy tale in which Blue Beard is a wealthy man who had a blue beard that made him so frightfully ugly. His appearance made girls run away from him. Blue Beard wanted to marry one of the two daughters of a fine lady but they rejected him on account of his blue beard and disgusted that he has already been married to several wives whose cause of deaths are never known. Blue Beard unable to get into marriage arranges for a feast. He tricks the ladies to gain their affection knowing that women are fond of riches and entertainment. The younger daughter accepts the man because of his riches. The riches of his place made her to perceive him less ugly than before. Marriage took place right after the vacation. Blue Beard and the girl lived together about a month. One day he got with some business in the country side that would last for weeks. He was considerate of her loneliness and when he left, he allowed for her friends and acquaintance to pal around in his absence.

Unlike the third person narrative in Blue Beard, The Bloody Chamber's narration is in first person in a girl's point of view. Feminist perception of the tale starts from here. The protagonist of The Bloody Chamber is an unnamed girl of seventeen year old. Marquis is a French aristocrat, he was in need of a wife. He had a tight face with monocle on his left eye. He had proposed the young girl for marriage. He was much older than the girl and was married three times before. All his three wives had a mysterious death and the corpses were never found. The girl was fascinated by his wealth and puzzled in his choice of opting her as a bride. She agreed for the marriage. Her mother asks her daughter to reconsider the marriage because she wants to make sure that her daughter really likes him for which the answer is yes. 
They get married in extravaganza and he takes her to his castle. Angela carter describes women's anxiety in opting into marriage life away from the comfortable and most liked mother's home. The girl feels the loss, ceasing to be the daughter of her mother by becoming the wife of a new man. She regrets the non-constancy of her identity. The mother stood divided between the feelings of joy and sorrow on her daughter's wedding day. The state of the bride and the bride's mother is brought to spot light whereas, in Blue Beard the mother and elder sister of the young girl didn't object for the marriage and readily marry her to the strange old man. The mother may have counseled or warned her of the marriage but there is no sufficient information on the wedding and the reader comes to the thought that her mother is greedy enough to marry her daughter to an old man with ugly blue beard whose wives are mysteriously dead.

The mother of the girl is described as someone so bold, brave and compassionate. Mother was widowed in a very young age left with a child but she was successful in growing the child all alone. She didn't remarry to support her family. In her hardship, she trained herself to use the revolver that her husband left behind. She was aware that society would take advantage of the ladies being alone and trouble them, so she carried the revolver in her reticulate always. The girl of Bloody Chamber describes her mother as,

My eagle-featured, indomitable mother; what other student at the Conservatoire could boast that her mother had outfaced a junkful of Chinese pirates, nursed a village through a visitation of the plague, shot a man-eating tiger with her own hand and all before she was as old as I? (2)

Charles Perrault has created dependent women characters on the contrary, Angela Carter produces professionally successful women who are talented and independent. The first wife of Marquis is a talented Opera singer who is successful in career and she is capable of living on her own. The second wife was a passionate model for a famous symbolist artist. The third wife was the Romanian Countess of high fashion. The newly married young girl is efficient in playing piano. Angela Carter displays the importance of education to women as it makes them strong and high spirited. Any form of education be it arts or academics enables women to have an identity on their own and display themselves potential. Angela Carter replaces the girl in Blue Beard with some strong witty girl. The young girl feels confident and comfortable when she is on her student costume. Her identity makes her feel herself whereas the dress given by her husband though elegant and extravagant gives the burden of being under the ownership of his husband.

The marital sex was perverse and she feels like being in a brothel. Her husband only beds her. When she thinks of her husband, she only gets the thought of having sex with him. She feels spent. Marquis liked her innocence. Men always want women to be innocent, unaware of the world around and seek help for their needs. Marquis posed a lustful look on the girl and she was frightened. She felt a twinge when she realized she had fallen for the riches of the man. She also observes his connoisseur look and started looking at herself in the way her husband does. Though she never feels the way he describes her she accepts his description of her. She then realizes that she has been corrupted. Objectification of man is accepted by woman and they objectify themselves. She says "I seemed reborn in his unreflective eyes, reborn in unfamiliar shapes....in my innocence; he sensed a rare talent for corruption." (25)

Unlike in Blue Beard, Marquise didn't consider her loneliness. He gave her the bunch of keys to discover every room in the castle but not a secret chamber in the bottom of the tower. He says that is his private room where he would go when marriage is not fruitful and imagine himself wifeless. He also sends the piano-tuner for her help. The girl repeats the phrase 'I have to be contented' several times. She is not contented rather she is obliged to play along with whatever he bestows. But the girl doesn't want to be submissive and she knows what she wants. She was so bored, she cannot interact with anyone even the maid and the piano-tuner because her rank forbids friendship with the staff. She was unable to replace the love she got from her mother, even the old nurse. The girl dies for love from someone that may also be a maid of her house but she is left disappointed. She calls up her mother and sobs, unfortunately the line was so poor and disconnected. Mother boils up and takes for the journey hearing her daughter cry in the telephone. Mother was wise and sensed that something is not fine with her daughter. She doesn't ask help to anyone nor hesitant to face the situation. Carter portrays the mother as an avenging angel coming to save her daughter.

In Blue Beard, the girl was so curious to find out what is in the closet despite she had access to all the riches. She was not satisfied with her company and the praise but wanted more to explore. The greed to know what is prohibited was fired with curiosity. She had in mind the unhappy consequences with her disobedience but she couldn't overcome her temptation. 
In The Bloody Chamber, she roams about every room and gets into library, where she is frightened seeing the terrible titles of the books that had the instructions for torture. Marquis' favorite canvas was Out of Night We Come, Into the Night We Go. Women strive for freedom and enlightenment but when they get it they get back to their nightmare with mistakes of innocence. They become corrupted. Marquis had statues, canvas and books representing morbid, decadent and frail women. Marquis aestheticized the suffering of women. Observing this strangeness in her husband, she wanted to know the real personality of her husband as he was mysterious and introvert. She looks up his files for information on his personality but she never finds any. Angela Carter explains the bride's expectation to know her husband plain but the girl was bestowed with a masked husband. She at once decides to go into the forbidden chamber where she believes to see his true nature. But she finds the corpses of his former wives who were brutally killed by her husband. She panics at the sight of the dead bodies but gathers courage by thinking of her mother. When the girl finds out the real personality of her husband, her first thought was how to escape it. The thought of she being his next murder boiled up in her. She left the chamber and was clever to leave no proof of her visit.

In Blue Beard, by temptation, the girl unlocks the closet and finds the murders of her husband. Her crime is discovered by Blue Beard, she begs him for pardon which is of no avail. Then she tricks him by asking time to pray. She wanted the help of her brothers and cried out to Sister Anne to signal haste to her brothers. The cultural stereotype that man could avenge and not a lady. She didn't ask her sister for help. Sister Anne was portrayed stupid that she didn't ask her sister what the problem is but just did what is implied to her. Her brothers save the girl at the last minute. The men are portrayed as the mighty warriors, protector and brave. The moral brought up by Perrault was female curiosity leads to retribution and wifely disobedience.

In Bloody Chamber, the girl is discovered by the piano-tuner who was blind, kind and willing to help her. The girl and piano-tuner pal up. She was not guilty of her deed. She insists that she has done nothing wrong but her husband still has reason to kill her. When the piano-tuner says she doesn't deserve to be punished, she disagree him saying 'Who can say what I deserve or no?'(55) She doesn't want to give authority over her. She says, 'I only did what he knew I would.' (55)For which the piano-tuner responds saying 'Like Eve'. (55) God kept the tree of knowledge in garden of Eden to be eaten and make the sin happen. Eve is only the puppet of god's play and Eve just did what is expected. Angela Carter objects the passivity in women, she says,

To be the object of desire is to be defined in the passive case.

To exist in the passive case is to die in the passive case - that is, to be killed.

This is the moral of the fairy tale about the perfect woman. (xv)

The girl had accidentally dropped the key of bloody chamber in the blood. Though she washes and wipes the blood stain, it never vanishes and forms the symbol of heart. In the meantime, Jean-Yves, the pianotuner and the girl started loving each other. When Marquis returned and asked her to pass back the key, he finds out her disobedience, he is not shocked of her disobedience and her knowledge of his murders. Marquis expected this to happen. He scolded her and ordered her to get ready for the death ritual. The girl pleaded to let off her but to no avail. He held the key against her forehead and the heart symbol got transferred onto her forehead. The girl hoped for her mother and made an unsuccessful call up. She helplessly submitted herself to him. When Marquis was about to chop off the girl's head, the mother shot him in his forehead riding her horse. Like Medusa she made the man turn still, he might be shocked to see a lady in action and eventually die.

The puppet master, open-mouthed, wide-eyed, impotent at the last, saw his dolls break free of their strings, abandon the rituals he had ordained for them since time began and start to live for themselves; the king, aghast, witnesses the revolt of his pawns. (59)

Men play the puppet master and took charge of women from time immemorial. But now women break free from that clutch and explore life on their own. The passivity is broken and women revolted for their rights and freedom.

In Blue Beard, the girl inherits the entire wealth. She uses the money to marry her sister Anne to a young gentleman, buy captain's commissions for her brothers and the rest to marry herself to a very worthy gentleman. She led a happy married life. The girl didn't realize her fault of choosing wealth for marriage but shamelessly inherits the wealth. This shows her lack of self-esteem

The girl in Bloody Chamber inherits the enormous wealth but gives away most of it to charities. She turns the castle a school for the blind. The girl widowed was at seventeen and turned again to poverty. She tried her best to patch up. She starts a little music school in Paris and pay off quite well. She leads a 
contented life. There were many whisperings and gossips of them but as the three know the truth and convinced that they acted right, the mere chatter never harmed them. She remarries the piano tuner. The mark on her forehead didn't disappear. It remained on her to live with the evidence of her shame, gone sold out for riches. The typical fairy tale where the poverty and unhappiness is transformed to wealth and happiness through marriage, is remodeled in the re-writing.

Women have been mistakenly represented in literature and this passes on to generations. The epic woman is the man made woman and it's not the true female sexuality. Female sexuality is empowering and doesn't degrade women's potential. The ideal woman is the one who behaves the way man wants to fulfill his selfish needs. In literature of the past women's potential is not recognized and they are stereotyped as nothing from nowhere. The girl in the re-written tale conquers individual fears and moved from dependence to independence, innocence to maturity. The mother character in it was bold, independent, brave and wise. She was in no way inferior to man. Female autonomy should be brought out by surpassing possession and oppression by men. True enlightenment of women happens only when women protest against domestic violence. Women should be mature and independent by avoiding wifely subservience. Men stereotype women with their knowledge of epics and fairy tales but this re-writing of tale helps in decolonizing men's thought of women as the weaker sex.

\section{REFERENCES}

[1] Perrault, Charles. The popular story of Blue Beard, or, Female Curiosity: embellished with beautiful cuts. London. Great Britain. Ryle and Co., Printers. 1845. Print

[2] Carter, Angela. The Bloody Chamber and Other Stories. London. Penguin Random House UK. 1995. Print 